\title{
In Memoriam: Gertjan van Ommen (1947-2020)
}

\author{
Bartha Maria Knoppers ${ }^{1} \cdot$ Jasper Bovenberg ${ }^{1}$
}

Received: 18 November 2020 / Accepted: 19 November 2020 / Published online: 19 January 2021

(c) The Author(s), under exclusive licence to European Society of Human Genetics 2021

Our dear friend and interdisciplinary scholar, Prof. Gertjan van Ommen is no longer with us-hard to imagine international policy discussions and dreams without him. Gertjan never lowered his expectations for validated, evidence-based scholarship or if in the "dream" category, for a vision that could be energized into action.

A biochemist by training, Gertjan's interests and achievements spanned the universe of modern-day biomedical science, fundamental, applied, industrial, infrastructural, and societal; from the development of exon-skipping therapy for Duchenne Muscular Disease to presiding over HUGO to co-founding the first European Biobanking Research Resource Infrastructure (BBMRI ERIC). Vintage Gertjan, he took the fellow founders of this initiative to a Philip Glass performance of the Netherlands National Ballet, where he secured their commitment to set up this pan European infrastructure, during the break, on the balcony of the Amsterdam Opera.

The international standing and reputation of the European Journal of Human Genetics is testimony to the "Renaissance" nature of Gertjan. As its Editor in Chief, he opened up the pages of 'his' European Journal of Human Genetics to Ethical, Legal and Societal Impact studies. And as an ELSI researcher avant la lettre, he constantly engaged in public discussions and outreach on genetics and genomics. Always putting patients first, he just as tirelessly challenged Doomsday ethicists and bureaucrats. His observation 'you protect patients better against their doctor than against their disease', was just one of his trademark quips which has helped many a health administrator, ethicist, and lawmaker to find the right perspective and strike the proper balance between (perceived) risks and benefits of biomedical research.

As one of the founders and a Board member of P3G (now P3G2), he served as Treasurer for the lifespan of P3G. In his case, as Treasurer of P3G, genetics and "accountability" seemed to be a natural hybrid. Meetings could count on his acerbic wit and critical insight but also his professionalism. Always the first to ask questions, you had to be prepared!

As thesis supervisor, inventor, and collaborator, he was able to discuss and negotiate genomics, legal fine print and patent claims (he generously shared several), while mixing his advice with countless, well delivered, self-deprecating anecdotes, such as about his back-stage meetings and interviews with the likes of Neil Young, Frank Zappa, and Graham Parsons (he was a former Rock'n Roll journalist).

It may sound strange but his most endearing and refreshing quality was not only the respect in which he held his wife Ria but also his interest in the human underpinnings of research, in researchers and patients as human beings. You could count on Gertjan for advice and collaboration, 24/7/365, on all topics, across all countries.

Sadly, the world has to roll on without Gertjan. Luckily, he gave us enough inspiration to keep on rolling.

Bartha Maria Knoppers, Jasper Bovenberg

Jasper Bovenberg

legalpathways@legalpathways.eu

1 European Journal of Human Genetics https://www.nature.com/ ejhg 